\title{
Vestido de noiva rasgado: acordes intertextuais em Por escrito, de Elvira Vigna
}

\author{
Leonardo Augusto Bora* \\ "Cada aeroporto é um nome num papel" \\ Solidão que nada, Cazuza
}

Ruínas, rasuras, ranhuras, arranhões em um disco que gira na vitrola, embalando um ensaio de balé, numa sala com paredes espelhadas: o romance Por escrito, de Elvira Vigna, publicado em 2014, apresenta ao leitor os retalhos narrativos de uma mulher à deriva, Valderez, que se autodefine como uma "presença ausente" (Vigna: 2014, 64), corpo em trânsito que se reconhece nas "salas de espera" do mundo. Alguém que sem rodeios afirma, em meio a uma torrente de pequenos relatos endereçados ao companheiro Paulo, ex-amante - o homem que ela a um tempo deseja e rejeita, o corpo que ela procura por ser (muito) bom de cama: "Faço isso desde sempre. Sento em qualquer lugar que não seja um lugar específico. E fico. Nessa época, são aeroportos, halls de hotéis, quartos de hotéis e sarjetas de cidades desconhecidas" (Vigna: 2014, 16).

Tamanha é a atenção depositada nas descrições de hotéis e aeroportos (sem falar nas escadarias de um prédio específico, cenário de grande importância para o desenrolar da trama), que uma evidente entrada analítica é o conceito de "não lugar", constructo

\footnotetext{
* Doutor em Teoria Literária pela Universidade Federal do Rio de Janeiro (UFRJ).
} 
basilar da antropologia de Marc Augé, tão debatido na contemporaneidade - ou, como prefere Augé, "supermodernidade", complexo tempo-espaço em que aeroportos, estações, hotéis, parques e "redes a cabo ou sem fio" "mobilizam o espaço extraterrestre para uma comunicação tão estranha que muitas vezes só põe o indivíduo em contato com uma outra imagem de si mesmo" (Augé: 2014, 74-5). Em determinado momento, Valderez vai mais fundo na autoanálise (e na análise do seu entorno) e define o apreço pelos "lugares de passagem" enquanto "estratégia de sobrevivência": "Eu tive a minha, nesses não lugares que foram, são ainda, meus lugares. Estou sem saber, agora, se quero continuar. Não só a estratégia, como a sobrevivência" (Vigna: 2014, 65).

São tantas as idas e vindas que não raro o leitor se descobre perdido - caminhando em um labirinto ou rodando em um caleidoscópio. Ora, a própria narradora, no mais das vezes, se mostra hesitante, também confundindo dados, datas, nomes, destinos. Está-se diante de uma narrativa intervalar, agarrada à superfície nebulosa do "entremeio". Valderez é uma habitante desse "entremeio", visão descortinada a partir da possível aproximação com Michel Onfray, autor que desenvolve a ideia de que uma viagem começa quando "giramos a chave na fechadura da porta de casa" (Onfray: 2015, 35). O teórico diz o seguinte:

O primeiro passo instala, de fato, um entremeio que tem a ver com uma lógica especial: não mais no lugar deixado, ainda não no lugar cobiçado. Flutuando, vagamente ligado a duas margens, num estado de ausência de peso espacial e temporal, cultural e social, o viajante penetra no entremeio como se abordasse as costas de uma ilha singular. [...] 
De avião, de barco, de trem ou de ônibus, partilhamos um espaço comum no tempo de passagem de um ponto a outro. A cabine de voo, o convés, o vagão e o assento são habitáculos que oferecem ocasiões de proximidade ou mesmo de promiscuidade, que forçam ao relacionamento ou obrigam à conversação. Nesse microcosmo comunitário tem lugar uma intersubjetividade limitada no tempo. Ao chegar no aeroporto, na estação ferroviária, no porto, ou rodoviária, essa sociedade, na maioria das vezes, se desfaz. [...]

Reina nesses lugares uma atmosfera particular e consubstancial à circunstância do entremeio: um tipo de abandono semelhante ao das salas de espera médicas ou, melhor ainda, dos consultórios de analistas (Onfray: 2015, 35-6).

O trecho de Onfray parece cair feito uma luva: Por escrito expressa tal "geografia do abandono", mais enfatizando o "meio do caminho" do que os pontos de partida e chegada. A prosa de Vigna está situada em espaços de transição onde a narradora não se vê capaz de elucubrar reflexões acabadas - e talvez não deseje isso; talvez deseje o ato criador da escrita, o texto em jorro, sem obrigatoriedades. A pesquisadora Beatriz Resende observou tais aspectos e, em análise publicada na edição d'O Globo de 25/10/2014, abordou a questão:

Nenhum drama e nenhum afeto. Nenhum entusiasmo, nenhuma escolha intencional. Quase um "prefiro não", no modelo de "Bartleby, o escrivão", na personagem que prefere "ficar mais à margem, mais do lado. Em algum entre. Como sempre”. Não dá nem quer receber nada dos que a cercam. A inevitável realidade da vida com seus detalhes banais, isso 
é que precisa ficar por escrito. O não pertencimento total parece impossível, mas deve ser buscado (Resende: 2014).

Este trabalho, embebido do espírito que norteia a crítica de Resende e as proposições poéticas de nomes como Onfray e Augé, desdobra a ideia de "não pertencimento" a partir do próprio entrelugar da escrita de Elvira Vigna, observando o diálogo estabelecido com Vestido de noiva, peça de Nelson Rodrigues. Depois de lançar olhos para algumas fissuras do romance, serão projetadas ideias acerca do texto original de Rodrigues, sob a perspectiva comparatista que permite, ainda, diálogos com outras obras contemporâneas que tocam em temas análogos - caso de O fotógrafo e O professor, de Cristovão Tezza. Ao final, sugere-se que o diálogo intertextual e metalinguístico pode ser compreendido enquanto estratégia narrativa que fortalece o caráter transitório e inapreensível do texto de Vigna, pintura com menos contornos definidos e mais sugestões, sobreposições e formas esfumadas: palavras que se esfarelam, feito um papel esquecido no bolso de uma calça recém-retirada da máquina de lavar.

\section{Quedas, esperas, deslocamentos}

A primeira subdivisão de Por escrito tem o título $O$ fim das viagens. O início da obra, portanto, antecipa um "fim", algo irônico, bem ao gosto de Elvira Vigna - afinal, as páginas subsequentes apresentam ao leitor uma sucessão de deslocamentos geográficos anteriores, viagens cujos despojos (cartões de embarque, etiquetas de bagagem, fotografias "perdidas" na "memória" do aparelho telefônico, impressões anotadas sobre a mesinha do avião, fragmentos de notas fiscais que se deterioram nos compartimentos das mochilas) podem servir de matéria ficcional para a montagem de um quebra-cabeça. 
Um quebra-cabeça que também é uma carta: desconjuntada, mas uma carta ao interlocutor Paulo. O pesquisador Pedro Taam defende isso e provoca: "Ora, se o livro é escrito em forma de carta, [...] então não há tensão de fato, já que a narradora, obviamente, escreve o relato depois que os eventos aconteceram. [...] A tensão é só do leitor" (Taam: 2014).

Se não há "tensão de fato", nas linhas de Valderez, também não existem certezas. Para quem espera isso, o texto adverte:

As horas passadas em aeroportos são sempre iguais, então o que vou dizer aqui eu não sei mais se foi na volta de Paris ou na ida para qualquer outro lugar, ou se foi nessa última viagem, a do Rio, em que voltei esquisita, segundo você, e da qual não falei (Vigna: 2014, 94).

Em meio aos deslocamentos da narradora e protagonista (que é representante comercial de produtores de café junto a multinacionais do ramo, uma "executiva" que viaja por lugares do "Brasil profundo" e corta o céu do eixo Rio-São Paulo, a "ponte aérea”, passando, ainda, por destinos como Brasília, Curitiba, Recife e Paris), o leitor é apresentado a um quase invisível (e cortante) fio narrativo. O papel de Valderez enquanto mulher é problematizado por ela própria, o que é perceptível em contundentes reflexões acerca das opressões de gênero (um dos aspectos mais expressivos de Como se estivéssemos em palimpsesto de putas, outro romance de Vigna ${ }^{1}$ ) que se desdobram nas desigualdades do mercado de trabalho:

\footnotetext{
${ }^{1}$ Ainda no início deste romance, a narradora afirma, em crítica à visão machista que tende a reduzir uma mulher a um objeto sexual: "E, como eles, [João] também achava que, tendo buceta, pensar em pernas, braços e cabeça, ou seja, em uma mulher completa, seria esforço excessivo" (Vigna: 2017, 37).
} 
Sou a presença feminina, necessária para tempos de politicamente correto, em um ambiente só de homens. Fosse no Brasil eu não estaria na mesa. Lá ninguém está nem aí. Como é Europa, acharam melhor me convidar. Ou é prêmio de consolação pela minha iminente despedida, o correspondente a relógio de ouro e cartãozinho: pelos serviços prestados, funcionário exemplar, uns tapinhas nas costas, já todo mundo meio bêbado. Ainda não estão bêbados. Vão estar. Depois. Quando vierem as putas² (Vigna: 2014, 71).

Tais frames se sobrepõem a um conjunto de pequenos indícios (objetos, gestos, olhares, não-ditos) que dão colorido a uma fina, sutil e até mesmo previsível (o que soa intencional, dada a carga de indiferença processada pela narradora - sem falar na já mencionada ironia) trama de suspense. Tem-se, assim como se pode observar no igualmente recente $O$ professor, de Cristovão Tezza, o desenrolar de um enredo a partir de subtramas, reminiscências e suposições que figuram tão importantes quanto as miradas aleatórias e as descrições banais de um cotidiano enfadonho, repleto de compromissos burocráticos e encontros entediantes. Em um dado momento, Valderez constata: "Todas as salas de espera de todos os hospitais, clínicas de aplicação, médicos e laboratórios de análise têm televisões com a Ana Maria Braga" (Vigna: 2014, 285). Em outro, ela se dá ao trabalho de fazer "como se fosse uma lista de coisas de aeroporto, assim geral, que é para ver se me mantenho ainda longe, ainda por algumas linhas

\footnotetext{
${ }^{2} \mathrm{~A}$ menção à prostituição, neste e em outros momentos de Por escrito, também se conecta a Como se estivéssemos em palimpsesto de putas, sem falar que a temática está no cerne de Vestido de noiva, personificada na presença fantasmática de Madame Clessi.
} 
um pouco mais longe" (Vigna: 2014, 95). O que mais a desperta da letargia é o cheiro de pão de queijo, aroma (ou fedor?) que faz cócegas, das primeiras às últimas páginas (um leitmotiv peculiar), nas narinas da personagem. É o que se depreende do seguinte excerto:

Às vezes duvido das coisas que vivi. Quase sempre.

Escurece do lado de fora do aeroporto, mas o cheiro azedo de pão de queijo me tranquiliza. Uma coisa pelo menos está certa. Saí do evento com o torrefador, volto para São Paulo. Portanto, devo estar em aeroporto brasileiro. E estou. Todos os aeroportos, no mundo inteiro, têm carros, louras e babacas de terno.

Pão de queijo, só os nossos (Vigna: 2014, 145).

O odor nauseante, que ela confunde com o de "bosta de vaca" (Vigna: 2014, 139), é uma espécie de âncora para o real e para o Brasil, o país de origem - um dos únicos elementos capazes de diferenciar os não lugares, uma vez que as "cadeiras pré-moldadas" em que ela tanto espera com o notebook sobre o colo acabam por padronizar as experiências cotidianas. $O$ cheiro de pão de queijo é uma espécie de legenda olfativa que situa a personagem em um lugar (o Brasil) e a rouba dos "pensamentos soltos" que navegam sem destino, fazendo com que busque, a partir dos olhos e das palavras, pontos de conexão: "Tem o cheiro de pão de queijo em todos esses aeroportos, os brasileiros, quero dizer. Tem as mesmas caras de sempre, meio cafajestes, que brotam adubadas pelos restos de pão de queijo, guardanapos usados, copos com resto de coisas pretas" (Vigna: 2014, 95). Em $O$ professor, de Tezza, o leitmotiv é factual e desperta o protagonista, um acadêmico apegado a tradições, de seu "breve vazio de memória" 
(Tezza: 2014, 65): a renúncia do Papa Bento XVI, estampada nos jornais impressos que se depositam sobre a mesa do café da manhã. Tanto no romance de Tezza quanto no de Vigna, a junção dos retalhos (alinhavada pelos fios do "falso suspense") conduz o leitor a uma morte misteriosa: em Tezza, a morte de Mônica, esposa do narrador e protagonista Heliseu; em Vigna, a morte de Aleksandra, uma bailarina russa que "não entendia nada" e por pouco não se tornou cunhada de Valderez. Duas mortes de mulheres, portanto, e duas mortes que envolvem quedas. Em ambas as obras, é impossível não lembrar da arquitetura narrativa de Mrs Dalloway, de Virginia Woolf, marco do romance em fluxo contínuo, as personagens que morrem despencam de janelas de prédios. Tais quedas compõem cenas imprecisas, pontuadas de raiva e rancor, imersas em discussões. Aleksandra cai vestida de noiva, desenho narrativo de inegável apelo. Vigna, por meio da voz de Valderez, flerta com o tragicômico (de novo, a noção de "entre") e acena, mais uma vez, para a ironia: a bailarina não morre devido à queda, que é "amaciada" pela "latada de chuchu" cultivada pelo porteiro; ela morre, dois dias depois, de septicemia, delirando palavras russas em um leito de hospital. O "único defunto direto do acontecimento", a narradora informa, é um pássaro cuja gaiola ficava debaixo do gradil de onde pendiam os chuchus:

Aleksandra está lá embaixo, as pernas abertas em uma posição estranha, o vestido de noiva levantado até a cintura, um sangue que mal se distingue dos outros sujos do vestido já sujo desde sempre.

Não morreu, o que só vamos saber depois.

A latada de chuchu do porteiro, o senhor Carlos, mais uns 
varais e um puxadinho totalmente irregular, segundo o síndico, amortizam a queda. Isso e mais o anu-preto do senhor Carlos, cuja gaiola fica embaixo do chuchu, e que é o único defunto direto do acontecimento.

Aleksandra vai morrer de septicemia dois dias depois, no hospital (Vigna: 2014, 192).

Como ironia pouca é bobagem, Valderez não poupa detalhes e fala da dificuldade enfrentada ao tentar traduzir a palavra "chuchu" para os amigos russos de Aleksandra, que desconheciam o vegetal tão popular quanto menosprezado, associado à ausência de gosto. A opção encontrada, polissêmica, foi transformar os chuchus em maracujás, os frutos da "paixão" - conhecidos pelo intenso perfume e pelo inconfundível sabor.

Chama a atenção, aqui, a dose de farsesco que permeia a obra, o que pode enganar um leitor desavisado. Se, por um lado, notam-se as vivas tintas do hiperrealismo ou neonaturalismo também observáveis em um romance como O fotógrafo, de Tezza, com descrições de "mijadas", órgãos genitais, microdetalhes de corpos e objetos que chegam a tocar o grotesco e o escatológico, o que mais salta aos olhos é o artificialismo do teatro - a abertura de uma outra possível porta para se acessar o cerne narrativo. O trunfo do romance, para Beatriz Resende, está na capacidade que Vigna demonstra ao conduzir o leitor por um universo de apagamentos e trivialidades que tendem a minimizar a tragédia central e a criar uma espécie de roteiro em que as rubricas valem mais que os diálogos: "Um suicídio ou assassinato ou acidente, mesmo no centro dos movimentos narrativos não faz muita diferença, porque a morte, como a vida da dançarina russa, importa pouco" (Resende: 2014). É o mergulho "num papelzinho 
ou em notas mentais", portanto, o que torna a leitura de Por escrito, aos olhos da pesquisadora, uma "experiência original". Caso o leitor não consiga mergulhar em tais "vagas", a experiência pode se revelar irritante: a frieza, a secura, a letargia, a não-presença de Valderez (que não testemunha o momento em que Aleksandra cai, por exemplo, porque estava sentada na escadaria do prédio, esperando por esperar) consomem as cerca de trezentas páginas da obra, "sem partidas ou voltas que importem muito" (Resende: 2014).

Um romance intitulado Por escrito, que apresenta ao leitor as "confissões" de uma narradora ao homem que só conhecemos a partir do olhar dela própria, trata do ato de escrever, a narração em sentido amplo - e a construção de personagens (e interpretações, versões, contradições, condenações e/ou absolvições) a partir delas, as palavras narradas. Resende sublinha isso ao sugerir que "mais do que o que é narrado, importa aqui o ato mesmo de escrever. Como fica a vida quando ela é escrita, anotada, reescrita, expondo-se não como fala ou relato, mas como um texto deixado na tela do computador, o eu por escrito" (Resende: 2014). Compreendido isso, não é difícil entender o porquê de Vigna encontrar na intertextualidade uma ferramenta poderosa - e é importante notar que os ensaios intertextuais também aparecem nas mencionadas obras de Tezza, como o diálogo com Ilusões perdidas, de Honoré de Balzac, obra traduzida em filme, cujo trailer adquire importância para a construção de O fotógrafo, destacando-se a metalinguagem: "Sob a luz de velas, o jovem Luciano de Rubempré escreve febrilmente diante de uma escrivaninha escura" (Tezza: 2004, 63). Um jogo de espelhamentos cujos reflexos não são exatos, conforme será visto na sequência. 


\section{Rasgando o véu de Vestido de noiva}

O mais evidente, aliás explícito, diálogo intertextual de Por escrito não poderia ser outro que não com um texto teatral. A tragédia de Aleksandra e os desdobramentos dela estão amarrados a uma montagem de Vestido de noiva ("adaptação musical que nunca houve", conforme a narradora escreve, repetidas vezes), de Nelson Rodrigues, e à tragédia de Alaíde, que também falece em um cenário hospitalar, após um atropelamento cercado de mistérios ${ }^{3}$. No romance, os personagens se veem conectados ao redor da tradução do texto de 1943 para um espetáculo de balé dirigido por Zizi, então esposa do amante de Valderez, Paulo, e protagonizado pela bailarina russa, Aleksandra (Alaíde), então noiva do irmão de Valderez, o pianista Pedro, personagem ambíguo: "Aleksandra se apaixona por Pedro. Sabe que ele é gay. Não se importa. Tenta trepar com ele" (Vigna: 2014, 60). Não se trata de mera opção aleatória, inserção gratuita de um texto no coração do outro: Vigna manipula ecos narrativos, evocando a peça rodriguiana mesmo em detalhes e momentos que passam longe das cenas na Escola de Dança ou na sala do apartamento de Molly, mãe de Valderez e Pedro, o cenário inicial do "acidente" que resulta na morte da russa. A imbricação é delicada - basta a constatação de que Aleksandra, a intérprete de Alaíde (que na peça desposa um personagem chamado Pedro, o namorado/noivo/marido roubado da irmã, Lúcia, inicialmente apresentada como a "Mulher de véu"),

\footnotetext{
${ }^{3}$ Sobre os espaços hospitalares, diz Augé: "Um mundo onde se nasce numa clínica e se morre num hospital, onde se multiplicam, em modalidades luxuosas ou desumanas, os pontos de trânsito e as ocupações provisórias [...], um mundo assim prometido à individualidade solitária, à passagem ao provisório e ao efêmero, propõe ao antropólogo, como aos outros, um objeto novo cujas dimensões inéditas convém calcular antes de se perguntar a que olhar ele está sujeito" (AUGÉ: 2014, 73-4).
} 
estava noiva, na "vida real" descrita nos relatos, de outro Pedro, o irmão de Valderez. E estava prestes a protagonizar um espetáculo de balé estruturado da seguinte forma:

A adaptação musical que nunca houve de um "Vestido de noiva" imaginado por Zizi tinha três núcleos, como no original de Nelson Rodrigues. Em cada núcleo, uma direção de cena independente das outras. Os núcleos eram estabelecidos através da iluminação, sem divisão física, concreta, do palco. Tem o núcleo da alucinação, o da memória e o da realidade. Essa é a divisão que está no texto de Nelson Rodrigues. Aleksandra ganha o papel de Alaíde, a noiva de Pedro, de quem já era na vida real. Outro Pedro, porque o personagem de Nelson Rodrigues também se chama Pedro. Alguns dos diálogos existentes no texto original, mantidos na montagem, entravam em off, fantasmáticos. Aleksandra não entende nada. [...] Nunca entendeu o que era humor. Aleksandra não entende nada (Vigna: 2014, 119).

O trecho reposiciona a ironia: o contraste entre a descrição de Aleksandra, a russa que não consegue decodificar o humor de Nelson Rodrigues (afinal, "não entende nada"), e os detalhes patéticos da morte que se aproxima, durante os ensaios gerais. Sobram palavras como "louca", "insuportável" e "desequilibrada", o que, no conjunto, colore uma personagem frágil, intempestiva, desconectada da realidade - e vítima do secular machismo, que a própria Valderez, abraçada às contradições performativas, reproduz (ela, Valderez, era chamada de "louca" por Molly; ela, Valderez, chamava Aleksandra de "louca"). Artificial, no limite: 
é uma russa que mora no Méier, subúrbio de "calor senegalês"; é uma estrangeira que deseja a cidadania brasileira e por isso aceita se casar com Pedro (segundo Valderez, se apaixona por Pedro), homossexual (que em dado momento se apresenta como Drag Queen) que desejava conhecer a Europa e viajar para longe - e que termina por se casar, anos depois, com um francês, Igor. Valderez foi à comemoração do casamento, em Paris - os relatos da viagem são o ponto de partida do romance. É a visão de uma foto de Aleksandra vestida de noiva, pronta para o espetáculo, em um porta-retrato sobre o piano de Pedro (que se culpava, pois rompera o noivado depois da entrada no cartório - manias persecutórias, medo de que a Polícia Federal descobrisse a farsa, dúvidas sobre o caráter de Aleksandra e a própria sexualidade), é a foto, na sala do apartamento do casal, o estopim para uma explosão de lembranças, traumas e autoanálises.

$\mathrm{O}$ artificialismo de Aleksandra, personagem que parece entrar na trama para morrer e só, conforme o defendido por Resende, expõe as suas arestas se pensarmos em Alaíde, a noiva falecida de Nelson Rodrigues. A incompreensão do papel dançado no palco leva Aleksandra ao mesmo fim da personagem espelhada - uma espécie de não compreensão de si mesma, na linha edipiana. Tanto na foto do porta-retrato (enviada por Molly a Pedro, depois da tragédia consumada, em situação incerta e até suspeita) quanto na queda da janela do apartamento de Molly, o vestido de noiva é um figurino teatral, uma fantasia quiçá carnavalesca, a construção artificial de uma personagem incompleta. Entretanto, não apenas a morte é real como o semblante no momento do clique: o incômodo de Valderez ao se deparar com a foto é proveniente disso, do enxergar de alguma "verdade" no sorriso congelado: 
É que Aleksandra me olha de dentro da moldurinha com um sorriso completamente imbecil, um sorriso que nunca vi nela. O sorriso de quem acha que vai ser feliz. Ela está com o véu e o vestido de noiva da Escola de Dança, o véu e o vestido imundos, rasgados e rasgáveis à menor pressão dos dedos, do armário de figurinos teatrais da Escola de Dança. [...] Em um momento que seja, ela acredita naquele véu e naquele vestido rasgados. E o fotógrafo pega justo esse momento (Vigna: 2014, 60-1).

No texto de 1943, Nelson Rodrigues manipula, em diferentes momentos, a ideia de "tanto faz." Basta o passar de olhos pelos seguintes excertos:

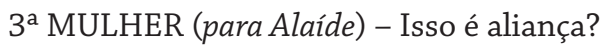

ALAÍDE (mostrando o dedo) - É.

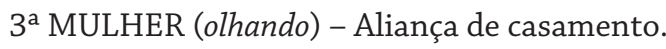

$2^{\mathrm{a}}$ MULHER - A da minha irmã é mais fina.

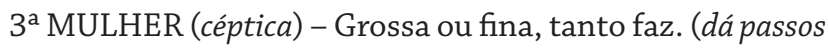
de dança) (Rodrigues: 1981, 112).

HOMEM - Ela disse - "matei eu noivo". Foi. Eu assisti.

ALAÍDE - Não assistiu nada! Não tinha ninguém. Lá não tinha ninguém! E não foi meu noivo. Foi meu marido! CLESSI (frívola) - Marido ou noivo, tanto faz (Rodrigues: 1981, 118).

Em contraste com tal senso de indiferença, outros momentos enfatizam determinadas certezas, como a infalibilidade da morte: 
MULHER DE VÉU - O que interessa é que você vai morrer. Não sei como, mas vai e eu então... me casarei com o viúvo. Só. Tipo da coisa natural, séria, uma mulher se casar com um viúvo.

(Alaíde senta-se. Mergulha o rosto entre as mãos. Luz no plano da alucinação.) (Rodrigues: 1981, 137).

Tal fala, inserida no Segundo Ato da tragédia, se dá em um plano da memória prestes a virar farelos, conforme o explicado nas rubricas do dramaturgo:

(A memória de Alaíde em franca desagregação. Imagens do passado e do presente se confundem e se superpõem. As recordações deixaram de ter ordem cronológica. Apaga-se o plano da memória. Luz nas escadas laterais. Dois homens aparecem no alto das escadas, cada um empunhando dois círios; descem, lentamente. A luz os acompanha. [...] Os dois cavalheiros estão no plano da alucinação) (Rodrigues: 1981, 134-5).

Em Por escrito, de forma análoga, o "tanto faz" é a regra (espécie de mantra interior da protagonista, viajante que desconhece elementos do próprio passado, a começar pela história do pai, e que liga os televisores dos quartos de hotéis apenas pelo ato de ligar um eletrodoméstico, pouco importando a programação ${ }^{4}$ ) que reforça a fatalidade das exceções - as mortes de Aleksandra e Molly e um gesto de Zizi, o gesto que oferece, ao final da obra, o combustível para um

\footnotetext{
${ }^{4}$ Diz o texto: "Ligo sempre a televisão, e sempre com o botão mudo. Só quero os movimentos na tela. Quem sabe me levam a produzir outros, nem que seja só com o dedo do pé” (Vigna: 2014, 133).
} 
manancial de interpretações. Respostas prontas, não há. Nem poderia haver: a ironia maior do romance reside na absorção das rubricas de Nelson Rodrigues, o que pode ser detectado nas seguintes afirmações de Valderez: "Tirando o mundo real, o resto continuava direitinho" (Vigna: 2014, 234); "É preciso criar um ambiente adequado, e ambientes adequados não são realistas. Nunca. Realidade estraga qualquer coisa" (Vigna: 2014, 258). Algumas indicações que Nelson deixou "por escrito", mais do que as falas das personagens, compõem a matéria regurgitada. Valderez, diante da encenação da tragédia que termina em tragédia de fato, no "cenário" hospitalar, nada mais é do que um "corpo estranho", uma sombra nas coxias, daí a autocomparação a um inseto, no trecho em que se refere a Paulo como o possível patrocinador do espetáculo protagonizado por Aleksandra:

Você vai no papel de cereja do sundae. Todo mundo quer. Você é o liaison. De você depende a aprovação do projeto. Nelson Rodrigues depende de você. O Brasil. Todo mundo. Todo mundo, não. Eu não dependo. No projeto "Vestido de noiva" (em qualquer projeto de vestido de noiva, mesmo os fora do palco), faço o papel de mosquinha (Vigna: 2014, 117).

Assim como no texto rodriguiano, encenado pela primeira vez em 28 de dezembro de 1943, no Theatro Municipal do Rio de Janeiro $^{5}$, os planos da memória e da realidade, no romance de Elvira

\footnotetext{
${ }^{5}$ Trata-se de uma data marcante para o que se convencionou chamar de "início do moderno teatro brasileiro". A companhia teatral Os Comediantes, sob direção de Zbigniew Marian Ziembinski, com cenografia e figurinos de Tomás Santa Rosa, causou um estrondo midiático sem precedentes, grafando em definitivo o nome de Nelson Rodrigues nas páginas da dramaturgia brasileira.
} 
Vigna, se veem corrompidos, em ruínas. Os delírios de Aleksandra, na cama do hospital (o plano da alucinação, portanto, se possível o paralelo com o texto rodriguiano), não são compreendidos, pois ela delira em russo. Se ela era uma pessoa que "não entendia nada", aqueles que a velam, no leito de morte, também não entendem nada - e o ciclo de não-entendimentos, não-ditos e não-resolvidos parece não ter fim; os espelhos se chocam e a narradora se despedaça em conflitantes versões (versos e reversos) de si mesma, como na cena em que, deitada em uma cama de motel, o motel barato em que "trepava" (termo utilizado à exaustão, maquinalmente) com o amante, Valderez se vê "fragmentada no espelho de várias faces grudado no teto" (Vigna: 2014, 52). É a mesma (ou seria outra?) Valderez quem define, quase ao final da obra, depois de refletir sobre a permanência dos destroços, repensando a morte de Aleksandra:

Aleksandra pega a foto que traz na bolsa e mostra. Molly olha a foto. Dá uma gargalhada.

A que escuto no degrau da escada, logo abaixo.

E aí tanto faz. E digo tanto faz, hoje, agora, depois de tudo que sei ou acho que sei, de tudo que não sei e não vou poder saber.

As duas se engalfinham e Aleksandra cai, por acidente, pela janela que está logo ali e que está aberta. Aleksandra fica quieta por uns segundos e simplesmente se deixa cair, de costas, pela janela, enquanto olha Molly, cai de costas, sem tirar os olhos de Molly, que acaba sua gargalhada. Em um outro caso, Molly tenta segurá-la. O tule rasga. Molly fica com o broche na mão (Vigna: 2014, 247). 
Suicídio, assassinato ou acidente, e Beatriz Resende já havia apontado para isso, "tanto faz". Assim como ao final da tragédia de Nelson Rodrigues, resta ao leitor/espectador, oculto nos bastidores, avaliar o benefício da dúvida.

\section{Assemblage}

Valderez reflete, em certo momento: "Porque eu não estava lá no começo. Estava. O meu habitual, e que mantenho, acho, até hoje, estar não estando. Eu estava na escada. Como sempre. No entre, no quase. No nada" (Vigna: 2014, 115). Ao se compreender enquanto pessoa existencialmente situada em um lugar indefinido, ou mesmo num lugar de ausências que se tornam presenças (a fantasmática negatividade de que tratam nomes como Giorgio Agamben), a personagem desvela uma condição errática e transitória. As verdades, nas linhas de Elvira Vigna, parecem (estamos falando, afinal, de um jogo de aparências - uma encenação, um ensaio) sempre provisórias - uma "possibilidade" deixada em aberto, conforme se depreende da leitura do último parágrafo do romance:

E ponho isso por escrito porque acho que posso não estar aí, presente, para te falar. Você e o cachorro, minhas falas na tela do computador, na tua frente. Porque pode ser que eu não esteja. Ou sou eu, que me obrigo a deixar essa possibilidade sempre aberta. E indo, vou devagarinho, num canto de cena, você nem percebendo na hora, quase sem perceber, comendo, passeando e eu, neste instante mesmo, indo (Vigna: 2014, 308).

A seleção lexical não é aleatória. Ao encerrar o romance com o verbo "ir" no gerúndio ("indo"), a autora intensifica o caráter transitório 
que permeia a narrativa, o não lugar, o meio do caminho, a ausência simbólica de portos de partida ou de chegada, algo que nos ajuda a compreender o fato, apontado por Pedro Taam, de que Vigna é uma autora preocupada com a estrutura das suas obras: "Essa preocupação com a forma é peça fundamental da literatura de Vigna" (Taam: 2014). A descontinuidade, portanto, é algo aparente, uma casca: mais um jogo de cena ensaiado (um véu, um disfarce narrativo) do que um exercício de escrita descompromissado com aspectos formais. Por detrás do "jorro" narrativo da protagonista, há o rigor de uma escritora consciente do seu fazer artístico. Valderez transita pelo espaço da negatividade (negatividade que, nos termos de Michel Foucault, está associada à ideia de loucura ${ }^{6}$ ), o que fica ainda mais evidente a partir da leitura dos seguintes fragmentos:

O caminho de um aeroporto para um centro urbano. Uma das linhas retas mais absurdas que conheço e as tenho, muitas.

Mas aqui, nessa linha reta, a desse nosso retorno do Rio de Janeiro e de uma morte que não é absurda porque absurdas são todas as mortes, há uma ironia. Estamos saindo de um aeroporto que não era o que devia ser. $\mathrm{O}$ voo, da ponte aérea, desceu em Guarulhos. Óleo na pista em Congonhas (Vigna: 2014, 234).

Tive na minha vida essas viagens que nunca acabavam nem começavam, de e para lugar nenhum, e onde eu passava a

${ }^{6}$ Diz o autor: "A loucura, portanto, é negatividade. Mas negatividade que se dá numa plenitude de fenômenos, segundo uma riqueza sabiamente disposta no jardim das espécies" (Foucault: 2012, 251). 
maior parte do tempo sem fazer nada, andando nas ruas, sentada em cadeiras pré-moldadas, deitada em colchas de hotéis baratos, olhando o negro das janelas de metrôs, o branco das janelas dos aviões, falando frases que não eram minhas. Desse período, tão longo, ficaram uns poucos dias. Uns porque nunca acabaram, outros porque nunca existiram, o anterior se debruçando sobre o novo que não conseguiu se instalar. (Vigna: 2014, 253).

A leitura dos trechos permite a iluminação de alguns pontos desenvolvidos ao longo deste trabalho: a sucessão de referências a "não lugares", conforme o observado na teoria de Marc Augé; o caráter teatral ou artificial (farsesco) da narrativa, produto de uma sofisticada experimentação formal; o questionamento dos limites da "realidade" - e, por conseguinte, da ficção ("tirando o mundo real, o resto continuava direitinho"); o destaque dado ao léxico que expressa a negatividade ("não", "nunca”, "nenhum", "nada”); a presença da ironia, apontada pela própria narradora ("mas aqui, nessa linha reta, a desse nosso retorno do Rio de Janeiro e de uma morte que não é absurda porque absurdas são todas as mortes, há uma ironia"). Ironia que transita, inclusive, no bailar de palavras como "nada" e "sempre", que expressam, respectivamente, o negativo e a totalidade: "Provavelmente, eu olhava o nada, que é o que sempre olho" (Vigna: 2014, 297). O tempero da probabilidade é a "cereja do sundae", para usar do mesmo clichê empregado pela narradora, ao se referir ao papel de patrocinador desempenhado por Paulo.

Coroando tal entendimento, deve-se destacar que o diálogo intertextual com Vestido de noiva, de Nelson Rodrigues, não apenas intensifica o caráter metalinguístico do romance (que é 
uma reflexão sobre o ato de escrever, vide as ponderações de Resende) como instaura de vez um espaço de indefinição, um não lugar da escrita, uma zona conflituosa marcada por estilhaços (especulares e especulativos). É possível vislumbrar, por fim, o entendimento de que Por escrito é um questionamento sobre a liberdade de ser: as viagens, as conexões e desconexões, as horas de espera em lugares impessoais, tudo isso conduz Valderez a uma gaveta de questionamentos últimos, que adquirem materialidade diante da face da morte, personificada no espectro fotográfico de Aleksandra: afinal, o que é ser livre? É possível ser livre, burlando os esquemas impostos pelas relações familiares, o mercado de trabalho, as convenções sociais, os ponteiros dos relógios? É possível escolher, viver ou fantasiar uma outra vida? Ora, não parece descabido supor que a obsessão de Alaíde pela memória de Madame Clessi, fascínio que brota a partir dos relatos que a cafetina deixou por escrito em um diário, expressa uma tentativa (malfadada, dado o acidente e a morte) de fantasiar uma outra existência. Nos termos de Sábato Magaldi, "Alaíde transfere para Madame Clessi, mundana assassinada por um adolescente, no começo do século (XX), os impulsos de fantasia e grandeza" (Magaldi: 1981, 17). Num romance onde o suspense é apenas aparente, como assinalou Taam, a narradora e protagonista Valderez baila em suspensão, mergulhada em lembranças disformes, experimentando, nessa permanente transição, o sabor agridoce da liberdade - e sendo, consequentemente, julgada "louca":

Nesse dia, pego minha mochila e vou para a rodoviária do Rio sem saber o que faria a seguir. Compro uma passagem para uma cidade cujo nome me pareceu bonito. Subo no 
ônibus. Vou. Passo a noite no hotel. No dia seguinte, volto. Molly puta, aos berros, eu sou louca (Vigna: 2014, 237).

Rebrilham os espelhamentos: "louca" é um termo proferido por Alaíde, em seus delírios durante a cirurgia:

$3^{\text {a }}$ MULHER - Você é casada?

ALAÍDE (fica em suspenso) - Não sei. (em dúvida) Me esqueci de tudo. Não tenho memória (impressionada) Mas todo o mundo tem um passado; eu também devo ter - ora essa! $3^{\text {a }}$ MULHER (em voz baixa) - Você o que é, é louca. ALAÍDE (impressionada) - Sou louca? (com doçura) Que felicidade! (Rodrigues: 1981, 112).

No início de História da loucura, Michel Foucault afirma que desde o medievo persiste a crença de que o "louco" é "um prisioneiro no meio da mais livre, da mais aberta das estradas: solidamente acorrentado à infinita encruzilhada. É o Passageiro por excelência, isto é, o prisioneiro da passagem" (Foucault: 2012, 12). Na sequência, o filósofo explica: "E a terra à qual aportará não é conhecida, assim como não se sabe, quando desembarca, de que terra vem. Sua única verdade e sua única pátria são essa extensão estéril entre duas terras que não lhe podem pertencer" (Foucault: 2012, 12). A condição "passageira" de Valderez, desnudada em Por escrito, é algo candente, terreno fértil para futuras investigações. Talvez distante da visão planificada de felicidade, Por escrito é um romance com arestas e feridas entreabertas - que às vezes cortam, às vezes sangram. Cabe ao leitor encontrar a sua entrada, a sua estrada, o seu espelho quebrado. 


\section{Referências}

AUGÉ, Marc. Não Lugares: Introdução a uma antropologia da supermodernidade. Campinas: Papirus, 2014.

FOUCAULT, Michel. História da loucura. São Paulo: Perspectiva, 2012. MAGALDI, Sábato. Introdução. In: RODRIGUES, Nelson. Teatro completo de Nelson odrigues. Rio de Janeiro: Nova Fronteira, 1981, pp. 7-38.

ONFRAY, Michel. Teoria da viagem: poética da geografia. Porto Alegre: LPM, 2015.

RESENDE, Beatriz. Elvira Vigna acompanha personagem indiferente ao mundo ao seu redor. O Globo, 25/10/2014. Disponível no seguinte sítio: https://oglobo.globo.com/cultura/livros/ elvira-vigna-acompanha-personagem-indiferente-ao-mundo-ao-seu-redor-14349932. Acesso em 16/11/2020.

RODRIGUES, Nelson. Vestido de noiva. In: RODRIGUES, Nelson. Teatro completo de Nelson Rodrigues. Rio de Janeiro: Nova Fronteira, 1981.

TAAM, Pedro. Por escrito. In: São Paulo Review, 05/01/2014. Disponível no seguinte sítio: http://saopauloreview.com.br/ resenha-por-escrito/. Acesso em 14/11/2020.

TEZZA, Cristovão. O fotógrafo. Rio de Janeiro: Rocco, 2004.

. O professor. Rio de Janeiro: Record, 2014.

VIGNA, Elvira. Por escrito. São Paulo: Companhia das Letras, 2014. . Como se estivéssemos em palimpsesto de putas. São Paulo: Companhia das Letras, 2017. 


\section{Resumo}

Uma das formas de acesso ao cerne narrativo do romance Por escrito, de Elvira Vigna, publicado em 2014, é a análise do mais explícito diálogo intertextual empreendido pela autora: a presença de uma tentativa de montagem de Vestido de noiva, peça de Nelson Rodrigues originalmente encenada em 1943. Por detrás das cortinas da "adaptação musical que nunca houve", jazem escondidas incontáveis reflexões sobre o caráter das personagens (especialmente da narradora e protagonista, Valderez, e da bailarina russa Aleksandra, a intérprete de Alaíde) e sobre o próprio processo de escrita, o que dá a Por escrito o teor metalinguístico observado por Beatriz Resende em crítica publicada n'O Globo, em 26/10/2014. $\mathrm{Na}$ visão de Resende, Vigna redigiu uma história marcada por "nenhum drama e nenhum afeto" - história cuja protagonista prefere ficar à margem, transitando pelos não lugares. A menção aos três planos da peça de Rodrigues conduz o leitor a um emaranhado de dúvidas e questionamentos - centelhas criativas deste trabalho, que lança questionamentos acerca da transitoriedade (dança entre "liberdade" e "loucura") da prosa de Elvira Vigna.

\section{Palavras-chave: Intertextualidade; metalinguagem; não lugares; Por escrito; Elvira Vigna.}

\section{Abstract}

One of the ways of accessing the narrative core of the novel Por escrito (In written form), by Elvira Vigna, published in 2014, is the analysis of the most explicit intertextual dialogue undertaken by the author: the presence of an attempt to assemble Vestido de noiva, Nelson Rodrigues' play originally staged in 1943. Behind the curtains of the "musical adaptation that never happened" there lie hidden countless reflections on the character of the characters (especially by the narrator and protagonist, Valderez, and the Russian ballerina Aleksandra, the interpreter of Alaíde) and the writing process itself, which gives to Por escrito the metalinguistic 
content observed by Beatriz Resende in a review published in $O$ Globo, on 10/26/2014. In Resende's perspective, Vigna wrote a story with "no drama and no affection" - a story whose protagonist prefers to stay on the sidelines, moving through the "non-places"'. The mention of the three planes of Nelson Rodrigues' play leads the reader to a tangle of doubts and questions - creative sparks of this paper, which cast questions about the transience (dance between "freedom" and "madness") of Elvira Vigna's prose.

Keywords: Intertextuality; metalanguage; non-places; Por escrito; Elvira Vigna. 